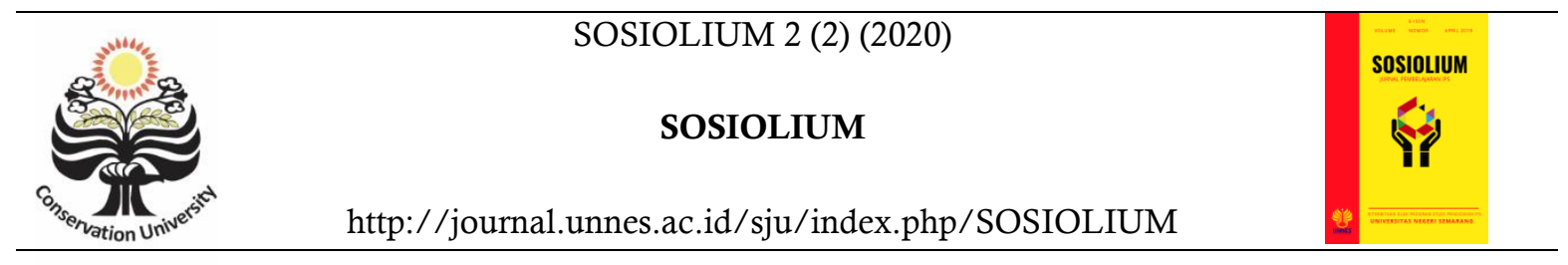

\title{
PENGUATAN PERILAKU TOLERANSI DALAM PEMBELAJARAN IPS DI SMP PANGUDI LUHUR SALATIGA
}

\author{
Bagja Riyanto, Puji Lestari ${ }^{\bowtie}$
}

Prodi Pendidikan IPS, Fakultas Ilmu Sosial, Universitas Negeri Semarang, Indonesia.

\section{Info Artikel \\ Sejarah Artikel: \\ Disubmit: Juli 2020 \\ Direvisi: Agustus 2020 \\ Diterima: September 2020}

\section{Keywords: \\ Strengthening, \\ Tolerance, Social \\ Studies Learning}

\begin{abstract}
Abstrak
SMP Pangudi Luhur Salatiga adalah salah satu sekolah yang telah menggambarkan adanya keberagaman, dari segi agama, etnis, sosial ekonomi, dan jenis kelamin/gender. Artikel ini bertujuan untuk 1) Menjelaskan penguatan perilau toleransi dalam pembelajaran IPS di SMP Pangudi Luhur Salatiga. 2) Mengetahui faktor pendorong dan penghambat dalam penguatan perilaku toleransi dalam pembelajaran IPS di SMP Pangudi Luhur Salatiga. Hasil dari penelitian ini menemukan bahwa 1) Penguatan dapat dilakukan tahap perencanaan melalui pengintegrasian pada RPP; Pelaksanaan melalui beberapa stimulus agar menjadi pembiasaan pada peserta didik (respon) untuk berperilaku toleran (awal, inti dan penutup; Evaluasi berupa jurnal yang telah dibuat oleh guru. Proses pembelajaran IPS di SMP Pangudi Luhur Salatiga juga berpegang pada nilai-nilai kepangudiluhuran seperti percaya pada Tuhan, rendah hati, teladan baik, mencintai sesama, bijaksana, lembut hati dan semangat serta teguh hati. 2) Faktor pendorong diantaranya lingkungan sekolah, materi pembelajaran, metode pembelajaran, kesadaran dan frekuensi, sedangkan faktor penghambatnya guru kurang dibekali dengan pelatihan, kondisi tak terduga, pengawasan dan sarana/prasarana.
\end{abstract}

\begin{abstract}
SMP Pangudi Luhur Salatiga is one of the schools that has illustrated diversity, in terms of religion, ethnicity, socio-economy, and gender / gender. This article aims to 1) explain the strengthening of tolerance behavior in social studies learning at SMP Pangudi Luhur Salatiga. 2) Knowing the driving and inhibiting factors in strengthening tolerance behavior in social studies learning at SMP Pangudi Luhur Salatiga. The results of this study found that 1) Strengthening can be carried out in the planning stage through integrating the RPP; Implementation through a number of stimuli so that students become accustomed (response) to tolerant behavior (initial, core and closing; Evaluation in the form of journals that have been made by the teacher. God, humble, good role model, loving others, wise, soft-hearted and enthusiastic and determined. 2) The driving factors include the school environment, learning materials, learning methods, awareness and frequency, while the inhibiting factors are teachers lack of training, poor conditions. suspect, supervision and facilities / infrastructure.
\end{abstract}

\footnotetext{
$\triangle$ Alamat korespondensi:

E-ISSN 2685-4929

Gedung C1, Lantai 1, FIS Unnes

Kampus Sekaran, Gunungpati, Semarang, 50229

Email: pujilestari@mail.unnes.ac.id
} 


\section{PENDAHULUAN}

Indonesia adalah negara kesatuan yang penuh dengan keragaman. Indonesia lahir tidak hanya satu suku, ras, agama, dan etnis, melaikan beragam. Indonesia terdiri atas beraneka ragam budaya, bahasa daerah, ras, suku bangsa, agama, dan lain-lain. Keberagaman adalah sutau keniscayaan yang tidak bisa orang hindari. Adanya keberagaman tidak hanya menimbulkan dampak positif namun juga dampak negatif salah satunya adalah intoleransi. Untuk menjaga keberagaman tersebut salah satunya melalui aspek pendidikan.

Pendidikan adalah salah satu lembaga yang dapat menanmkan nilai toleransi, sebagaimana menurut Undang-Undang Sistem Pendidikan Nasional tahun 2003 Bab 3 pasal 4 ayat 1 menjelaskan "pendidikan di selenggarakan secara demokratis dan berkeadilan serta tidak diskriminatif dengan menjunjung tinggi hak asasi manusia, nilai keagamaan, nilai kultural dan kemajemukan bangsa". Lembaga pendidikan yakni sekolah yang tidak sedikit menerima siswa dengan segala jenis keragaman, sehingga menuntut pihak sekolah untuk menanamkan nilai toleransi kepada masing-masing siswanya agar pembelajaran dapat berlangsung dengan lancar. Sekolah memberikan ilmu pengetahuan melalui kurikulum pendidikan yang dapat diimplementasikan melalui beberapa pelajaran khususnya mata pelajaran Ilmu Pengetahuan Sosial (IPS). Ilmu Pengetahuan Sosial adalah program pendidikan yang membina peserta didik agar menjadi warga negara yang baik dalam suasana kedamaian. Indikator, setelah peserta didik mempelajarai IPS, akan memilki sejumlah kompetensi yaitu berkomunikasi, beradaptasi, bersinergi dengan baik dan selalu berpikir positif terhadap orang lain (Saidiharjo, 2004).

Dalam hal ini adalah di SMP Pangudi Luhur Salatiga, pemilihan SMP Pangudi Luhur Salatiga karena beberapa alasan diantaranya adalah pertama prosentase keberagaman dari segi agama Kristen Protestan sebanyak 63 atau 39\%, Kristen Katolik sebanya 58 atau $35 \%$, dan yang menganut agama Islam sebanyak 42 atau $26 \%$. Selanjutnya keberadaan etnis yang beragam di sekolah tersebut yakni Jawa dan Tionghoa. Kedua, terkait latar belakang sosial ekonomi dari peserta didik, berdasarkan hasil observasi menyatakan pada dasarnya pekerjaan orang tua peserta didik di SMP Pangudi Luhur Salatiga beragam ada yang wiraswasta, karyawan, pegawai PNS dan lain sebagainya.

Ketiga, kebijakan yang dibuat oleh sekolah melalui beberpa kegiatan atau kebijakan yang dilakukan oleh sekolah (perayaan hari besar agama yang mana peserta didik mengikuti tersebut dengan maksud dan tujuan menanamkan nilai toleransi beragama). Keempat, di sekolah tersebut terdapat kurikulum yang berbeda dari sekolah pada umumnya yakni kepangudiluhuran, hal tersebut juga diimplementasikan pada mata pelajaran kepangudiluhuran yang mengajarkan sepuluh nilai (percaya pada Tuhan, rendah hati, teladan baik, mencintai sesama, saleh, sikap bijaksana, lembut hati, tabah hati, berpengetahuan, dan semangat/keteguhan hati).

Kelima, sekolah tersebut juga tidak mengekslusifkan diri khususnya pada saat penerimaan peserta didik baru, berdasarkan pernyataan dari kepala sekolah SMP Pangudi Luhur menjelaskan bahwa prinsip dari sekolah adalah bagaimana peserta didik memperoleh pendidikan yang layak, berkualitas dan adil tanpa memandang perbedaan latar belakang. Keenam, visi dan misi yang dimiliki yang mana mendukung dalam proses penanaman toleransi segala aspek, memberikan pembinaaan dan penguatan berkaitan dengan budi pekerti luhur yang bekerjasama dengan guru dan wali kelas. Hal tersebut bisa menggambarkan terkait dengan proses penguatan nilai-nilai toleransi di sekolah tersebut. Berdasarkan latar belakang diatas peneliti berfokus terkait 1) Menjelaskan penguatan perilau toleransi dalam pembelajaran IPS di SMP Pangudi Luhur Salatiga. 2) Mengetahui faktor pendorong dan penghambat dalam penguatan perilaku toleransi dalam pembelajaran IPS di SMP Pangudi Luhur Salatiga.

\section{METODE}

Penelitian ini menggunakan metode penelitian kualitatif. Metode penelitian kualitatif ini digunakan sebagai prosedur penelitian yang menghasilkan data deskriptif berupa kata-kata 
tertulis atau lisan dari orang-orang yang diamati. Kirkl dan Miller dalam (Moleong, 2010:4) mendefinisikan bahwa penelitian kualitatif adalah tradisi tertentu dalam ilmu pengetahuan sosial yang secara fundamental bergantung dari pengamatan pada manusia baik dalam kawasannya maupun dalam peristilahannya. Sedangkan menurut Bogdan dan Taylor (dalam Moleong, 2010:3), metode penulisan kualitatif sebagai suatu prosedur penelitian yang menghasilkan data deskriptif, yaitu kata-kata tertulis atau lisan dari orang-orang dan perilaku yang diamati.

Penelitian ini menggunakan kualitatif deskriptif, sebab dalam hal ini akan menjelaskan secara detail fenomena terkait proses penguatan perilaku toleransi guru dalam pembelajaran IPS, dengan menggunakan kualitatif akan lebih jelas dalam mendeskripsikan fenomena penguatan perilaku toleransi yang dilakukan oleh guru dan faktor-faktornya. Lokasi penelitian ini berada di SMP Pangudi Luhur Salatiga. Pada penelitian ini yang difokuskan ialah penguatan perilaku toleransi oleh guru dalam pembelajaran IPS melalui tiga tahap yakni perencanaa, pelaksanaan dan evaluasinya, selain itu juga pada faktor pendorong dan penghambat dalam penguatan perilaku toleransi oleh guru dalam pembelajaran IPS. Sumber data dalam penelitian ini diperoleh melalui data primer dan skunder. Data primer diperoleh melalui observasi dan wawancara, sedankan data sekunder berasal dari dokumentasi berupa foto kegiatan pembeajaran dan dokumen berupa buku, jurnal ataupun artikel yang berkaitan. Uji validitas data yang digunakan dalam penelitian ini adalah dua triangulasi yakni triangulasi sumber dan teknik. Uji keabsahan data yang digunakan dalam penelitian ini adalah model interaktif Miles Huberman berupa pengumpulan data, reduksi data, penyajian data, dan penarikan kesimpulan atau verifikasi.

\section{HASIL DAN PEMBAHASAN}

\section{Penguatan Perilaku Toleransi dalam Pembelajaran IPS}

Berdasarkan hasil penelitian menyebutkan bahwa dalam proses penguatan perilaku toleransi dapat dimuat pada proses perencanaan pembelajaran pada saat pembuatan RPP.
Selanjutnya hal tersebut juga sesuai dengan dokumen RPP yang dimiliki oleh guru IPS terdapat nilai karakter toleransi/menghargai. Seperti pada umumnya dalam pelaksanaan terdiri dari tiga tahap diantaranya adalah Pendahuluan, pendahuluan adalah bagian yang tidak dapat dipisahkan dalam proses pembelajaran. Kegiatan pendahuluan disebut kegitan awal pembelajarn. Adapun bentuk kegiatannya diantarnya 1) menciptkan kondisi awal pembelajaran, 2) memberi acuan, 3) membuat kaitan (melakukan apresepsi) dan 4) melakukan test awal.

Berdasarkan hasil penelitian menyebutkan bahwa kegiatan pendahuluan yang dilakukan oleh guru IPS di SMP Pangudi Luhur Salatiga diantaranya adalah menciptakan kondisi awal pembeljaran biasanya melalui doa sebelum belajar, namun doa yang terjadi di SMP Pangudi Luhur Salatiga hanya di pagi hari. Doa menyesuaikan dengan kondisi sekolah yakni berdoa sesuai agama Katolik, bagi agama lain bisa menyesuaikan, dan memberikan apresepsi

Kegiatan Inti adalah kegiatan utama yang terjadi dalam proses pembelajaran. Dalam proses kegiatan inti untuk menguatkan toleransi yang terjadi di SMP Pangudi Luhur Salatiga tergantung materi yang akan disampaikan. Sebab tidak semua materi secara langsung mengadung pesan atau nilai-nilai toleransi. Semisal pada materi berfokus ekonomi, guru IPS tidak secara langsung menjelaskan nilai-nilai toleransi melainkan hal-hal apa saja yang bisa diambil dari bab saat itu (menghargai pembeli dan penjual). Hal yang sudah diperispakan dalam kegiatan inti akan terjadi mulai dari metode, sumber dan media pembelajaran yang digunakan. Pada proses kegiatan inti guru memiliki kesempatan yang cukup banyak untuk menguatkan perilaku toleransi. Akivitas nilai-nilai toleransi yang terjadi di tahap inti diantaranya adalah menghargai perbedaan pendapat, tanya jawab, tidak mengekslusivkan diri dan berbaur satu sama lain. Kemudian guru juga tidak lupa jika ada materi yang berkaitan dengan toleransi lingkungan sekitar (sekolah pada khususnya ataupun Kota Salatiga) dapat menjadi sumber belajar.

Implementasi pengutan perilku toleransi di era Pandemi Covid-19. Adanya kebijakan belajar dirumah saja menjadikan proses pembelajaran berubah dari yang awalnya secara luar jaringan 
(luring) menjadi dalam jaringan (daring). Proses pembelajaran IPS yang dilakukan guru di SMP Pangudi Luhur Salatiga melalui google form dan whatsapp group. Pandemi covid-19 kejadian yang diluar kendali alhasil menyebabkan sekolah belum siap. Keterbatasan sarana/prasarana yang dimiliki juga menjadi penyebab atau penghambat dalam proses penguatan nilai toleransi. Terkait dengan penugasan berdasarkan hasil penelitian bahwa guru jarang memberikan materi kepada peserta didik, hanya memberikan penugasa melalui whatsapp group, kemudian pengumpulan tugasnnya bisa dilakukan melalui langsung ke sekolah dan online.

Selanjutanya terkait dengan evaluasi pembelajaran dalam proses penguatan perilaku toleransi dalam pembelajaran IPS berupa jurnal sikap yang telah dibuat oleh guru. Guru IPS tidak ada penilaian evaluasi perilaku toleransi secara khusus, namun melalui jurnal sikap. Sebab menurut Menurut Green (2000) menyebutkan bahwa sikap merupakan salah satu faktor yang mempengaruhi perilaku. Evaluasi disini juga bisa dijadikan sebagai penilaian diri serta lembar observasi untuk penilai penerapan aktivitas peserta didik yang mencerminkan nilai toleransi.

Penguatan perilaku toleransi dalam pembelajaran IPS juga dapat disesuaikan dengan kurikulum kepengaudiluhuran diantaranya adalah nilai percaya kepada Tuhan, rendah hati, teladan baik, mencintai sesama, bijaksana, lembut hati, dan terkahir adalah semangat dan teguh hati. Kurikulum kepangudiluhuran diatas juga dijadikan sebagai nilai utama di SMP Pangudi Luhur Salatiga, selain itu nilai tersebut dapat diintergrasikan pada pembelajaran IPS

Faktor Pendorong dan Penghambat pada Penguatan Perilaku Toleransi dalam Pembelajaran IPS di SMP Pangudi Luhur Salatiga.

Adapun faktor- faktor dalam penguatan perilaku toleransi pada pembelajaran IPS di SMP Pangudi Luhur Salatiga, diantaranya adalah faktor pendorong dan penghambar. Pada faktor pendorong terdiri dari 1) lingkungan sekolah, $\mathrm{Hal}$ tersebut bisa dilihat melalui visi, misi dan tujuan SMP Pangudi Luhur Salatiga. Kemudian visi atau misi tersebut diimplementasikan melalui kebijakan atau program sekolah. Sebagai contoh perayaan hari besar, dengan adanya perayaan tersebut bisa menjadi indikator dalam penguatan toleransi di sekolah; 2) materi dan metode. Materi Pembelajaran akan mempengaruhi sebagai faktor pendorong dalam penguatan atau menguati perilaku pesert didik agar mengimplementasikan nilai-nilai toleransi. Materi sejarah khususnya kedatangan agama Hindu Budha akan lebih mudah sebagai penguatan perilaku toleransi; 3 ) kesadaran, peserta didik sudah mengetahui dan sadar akan kondisi SMP Pangudi Luhur Salatiga hal tersebut juga akan berdampak kesadaran yang terjadi pada pembelajaran IPS di kelas; dan 4) frekuensi, frekuensi disini lebih menitikberatkan pada sering tidaknya seorang guru memberikan penguatan (seperti pemberian peringatan, menanamkan nilai-nilai toleransi baik perilaku ataupun dalam proses pembelajaran di kelas).

Faktor penghambat diantaranya adalah Guru kurang dibekali dengan pelatihan. Pada proses pembelajaran IPS di SMP Pangudi Luhur Salatiga memiliki guru IPS yang berlatarbelakang bukan dari IPS sendiri melainkan dari bidang ilmu lainnya, kemudian kurangnya pembekalan terkait bagaiamana pengajaran IPS yang baik, menjadikan ketidakmampuan guru dalam menghadapi perubahan yang terjadi di sekolah;2) kondisi tak terduga. Pandemi covid-19 adalah kejadian yang tidak terduga, bahkan hasil wawancara menyebutkan saat itu guru belum melakukan persiapan hal demikian pula menjadikan hambatan dalam proses penguatan toleransi pada peserta didik; 3) pengawasan, dalam penguatan perilaku toleransi adalah pengawasan hal tersebut menyebabkan ketidaktercapainya tujuan yang diinginkan. Pengawasan ini dikarenakan setiap kelas mempunyai karakteristik yang berbeda dan hal terebut akan menjadi kendala bagi guru IPS dan tidak selamanya guru mengawasi aktivitas peserta didik setiap saat, jadi kadang ada perilaku peserta didik yang tidak terkontrol yang berdampak pada penguatan itu sendiri; dan 4) sarana dan prasarana, berdasarkan hasil penelitian, karena kekurangan sarana/prasarana yang dimiliki guru jarang memberikan materi, alhasil berpengaruh dalam proses penguatan pada peserta didik, karena tidak terjadinya interkasi secara langsung dan sistem pembelajaran IPS yang terjadi selama pandemi. 


\section{SIMPULAN}

Proses penguatan perilaku toleransi pada pembelajaran IPS di SMP Pangudi Luhur Salatiga pada dilakukan mealui proses pemberian stimulus yang dilakukan oleh guru agar terjadinya pembiasaan. Stimulus tersebut dalam pembelajaran IPS dapat ditemukan melalui pelaksanaan pembelajaran seperti melakukan doa sebelum dan sesudah kegiatan belajar, melalui teguran pada saat di kelas, berserta penilaian melalui jurnal. Selanjutnya, di SMP Pangudi Luhur Salatiga terdapat kurikulum lokal yakni kepangudiluhuran, tidak hanya dijadikan suatu muatan lokal, nilai kepangudiluhuran juga dapat dijadikan acuan dalam pembelajaran IPS.

Berjalan tidaknya penguatan perilaku toleransi pada pembelajaran IPS di SMP Pangudi Luhur dikarenakan dua faktor yakni pertama pendorong diantaranya lingkungan sekolah, materi pembelajaran, metode pembelajaran, kesadaran dan frekuensi, sedangkan faktor penghambatnya guru kurang dibekali dengan pelatihan, kondisi tak terduga, pengawasan dan sarana prasarana.

\section{DAFTAR PUSTAKA}

Bintarto, Yustinus Wahyu. 2020. Pengembangan Buku Pengayaan Pembelajaran Menulis Naskah Drama Dengan Mengintegrasikan Nilai Kepangudiluhuran Berdasarkan Pendekatan Kontekstual. Tesis. Universitas Sanata Dharma.

Djamarah, Syaiful Bahri. 2000. Guru dan Anank Didik (dalam Interaksi Edukatif). Jakarta: PT Rineka Cipta.

Maharani, Dyah dan Rosilawati. 2018. Pengaruh Pengawasan dan Pengendalian Terhadap Peningkatan Motivasi Kerja Pegawai di Kantor Kecamatan Serang Kota Serang

Moloeng, Lexy J. 2011. Metodologi Penelitian Kualitatif. Bandung: Remaja Rosda Karya. Nahar, Novi Irwa. 2016. Penerapan Teori Belajar Behavioristik dalam Proses Pembelajaran. Nusantara (Jurnal Ilmu Pengetahuan Sosial). Volume 1, Desember 2016.

Nana Sudjana 2010. Dasar-dasar Proses Belajar. Bandung: Sinar Baru Bandung.

Saidiharjo. 2004. Konsep Dasar Ilmu Pengetahuan Sosial. Yogyakarta: Prgram Pascasarjana UNY.

Undang-Undang Republik Indonesia nomor 20 Tahun 2003 Tentang sistem Pendidikan Nasional. Jakarta: Depdiknas. Ditjen Dipdasmen. 